\title{
Chromosome Organizaton in Simple and Complex Unicellular Organisms
}

\author{
Justin M. O'Sullivan* \\ Institute of Natural Sciences, Massey University, Auckland, \\ New Zealand
}

\begin{abstract}
The genomes of unicellular organisms form complex 3-dimensional structures. This spatial organization is hypothesized to have a significant role in genomic function. Spatial organization is not limited solely to the threedimensional folding of the chromosome(s) in genomes but also includes genome positioning, and the folding and compartmentalization of any additional genetic material (e.g. episomes) present within complex genomes. In this comment, I will highlight similarities in the spatial organization of eukaryotic and prokaryotic unicellular genomes.
\end{abstract}

\section{Introduction}

The relatively simple concept of chromosome folding obscures the fact that the higher order constraints that are imposed on chromosome structure are complex and poorly understood.(Rocha, 2008) It is known that the organization of genomes into a complex, dynamic, non-rigid 3-dimensional structures (Cabrera and Jin, 2006; Dekker et al., 2002; Duan et al., 2010; Miele et al., 2009; O'Sullivan et al., 2009; Rodley et al., 2009; Thanbichler et al., 2005; Zimmerman, 2006) reflects the open nature of the biological systems (Box 1) and their ability to exchange of energy with their surroundings in order to create and maintain order (Kauffman, 1993; Nicolis and Prigogine, 1977). Despite the fact that there are obviously systems required to alter and maintain this order, the identification of a single system that is responsible for the generation of genome organization is precluded by the fact that the spatial structure emerges from: the combined effects of the linear sequences of bases; the factors that recognize and act on the nucleotides; and limitations imposed by the chromosome(s) local and external environment(s). Therefore, while there are numerous systems that are capable of regulating chromosomal organization, individually or in combination the exact contribution of each system is currently unknown.

It is generally agreed that the spatial organization of chromosomes must be regulated to ensure that the genome remains dynamic and capable of adapting to the cells requirements. However, it remains to be determined if there are general or over-arching characteristics to the systems that regulate genomic structure through-out all branches of the tree of life. One would predict that this would be the case. Although, specific adaptations will undoubtedly occur in complex organisms where gene regulation, and hence global organization, is related to the fixation of developmental stages as opposed to the more immediate responses to

*Corresponding author: Email: j.m.osullivan@massey.ac.nz direct environmental perturbations seen in single celled organisms. Thus, the purpose of this short comment is to highlight some apparent commonalities between genome structure in simple and complex unicellular organisms. I will not present a detailed examination of all the literature pertaining to genome structure in single celled organisms, and interested readers are referred to recent, excellent, in depth reviews (e.g. Thanbichler et al., 2005; Toro and Shapiro, 2010; Zimmerman, 2006).

\section{Physical positioning correlates with position on the chromosome}

Genomes are not just stuffed into a cell or nucleus. Rather, once folded, they are orientated relative to cellular landmarks (Bystricky et al., 2005). This feature of genome organization is shared by both prokaryotes and single celled eukaryotes. For example, yeast chromosomes are orientated along the spindle pole body (SPB) - nucleolus axis such that the centromeres are clustered near the SPB and furthest away from the emerging yeast daughter cell (Bystricky et al., 2005). Moreover, prokaryotic origins of replication, which are often associated with the centromere-like sequences (Livny et al., 2007), also demonstrate non-random replication dependent asymmetric associations with the old and new cell poles, and cellular mid-section (Fogel and Waldor, 2005; Liu et al., 2010; Niki and Hiraga, 1998; Viollier et al., 2004; White et al., 2008). Prokaryotic origins of replication are also maintained within 'territories' (Fiebig et al., 2006) that are similar to those observed for eukaryotic centromeres (Bystricky et al., 2004) and genes (Berger et al., 2008). A non-trivial extension of the finding that centromeres/origins associate with nuclear/ cellular poles is the discovery that the physical positions of eukaryotic and prokaryotic loci, within the nucleus/cell, are strongly correlated with the distance of the locus from the centromere or origin of replication (Figure 1A; Berger et al., 2008; Breier and Cozzarelli, 2004; Thanbichler et al., 2005; Therizols et al., 2010; Viollier et al., 2004; Wiggins et al., 2010).

\section{Box 1 Open systems}

Open biological systems continuously exchange matter and energy with their surroundings in order to maintain and develop their structural integrity. Hence they delay their ultimate conversion into a disordered state, which is predicted by the second law of thermodynamics. In effect, the organisms' own entropy production is compensated by an influx of free energy, which makes entropy reduction and structural organization possible. As a consequence, the organism exits in a state of stationary nonequilibrium (Bischof, 2003; Kauffman, 1993; Nicolis and Prigogine, 1977; Prigogine, 1980; Von Bertalanffy, 1950). 

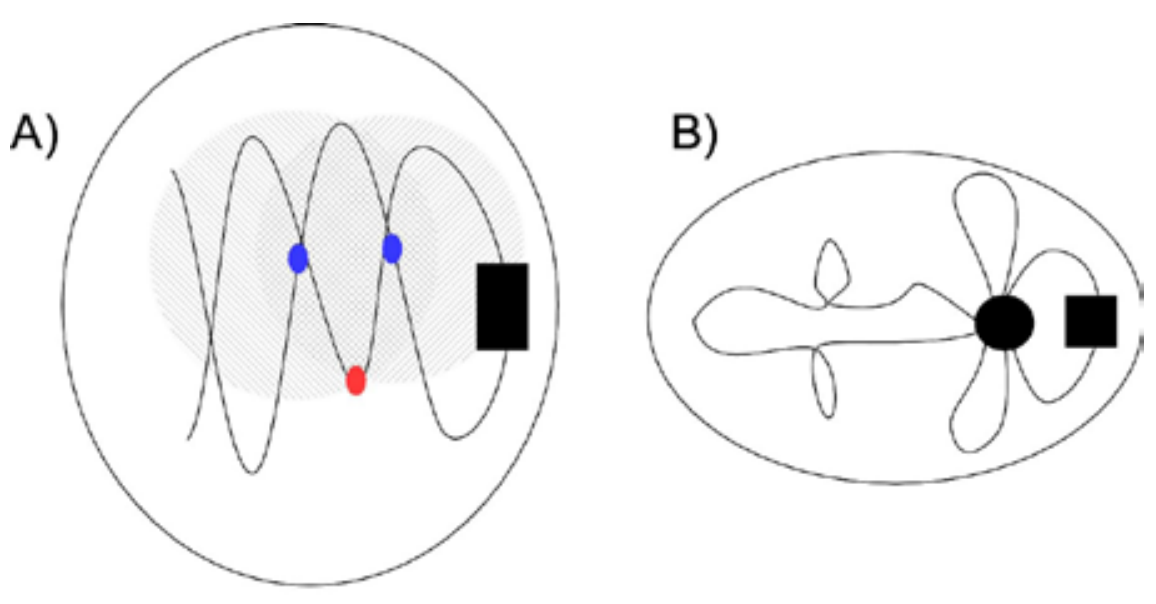

Centromere/Origin

proteinaceous boundary elements/chromosomal contacts

Zone of movement

Figure 1. Cartoon depicting genome organizations that maintain a linear relationship between the distance a locus is from the centromere/origin of replication, and its physical position along the nuclear/cell's long axis. A) Model depicting linear chromosome organization. Locus movement is limited by the domain/territory organizations that are formed by combinations of chromosomal contacts (either inter- or intra-chromosomal) or boundary elements. Movement in each direction is limited by the distance to the furthest boundary element (depicted by the diagonally shaded circles) and hence only occurs within the hatched zone. Nuclear position correlates with linear distance from the centromere/origin although there is no requirement that the increases are proportional to the linear distance. B) Model of non-complex circular genome organization. rDNA loci cluster to form a nucleolus-like structure. Loops are orientated to maintain the origin-termination region axis and the correlation between linear distance and physical position along the cell's long axis. The overall structure is dynamic, altering with the cell cycle and level of compaction according to the number of rDNA loci clustering in the nucleolus. Chromosomes within complex prokaryotic genomes will overlap but need not be oriented about the same fixed points.

In its simplest form, the positioning of genomes within a cell/nucleus requires that specific chromosomal loci connect with localized proteins present on the internal surface of the cell or nuclear membrane (Comings, 1968; Viollier et al., 2004). Such systems have been observed, for example the RacA protein associates with the origin proximal ram sequence in $B$. subtilis and anchors the replication origin to the cell pole via the polar DivIVA protein (Ben-Yehuda et al., 2003). However, it appears that a significant contribution to genome positioning is also made by the regulated formation of inter- and intra-chromosomal interactions (Figure 2) which provide a scaffold that correctly positions loci "as if the position is imprinted" (Liu et al., 2010). Intra-chromosomal interactions are an integral part of the regulation of bacterial, mitochondrial, and eukaryotic gene expression and genome organization (Balaeff et al., 2004; Dandanell et al., 1987; Martin et al., 2005; Schleif, 1992; Swigon et al., 2006; Wiggins et al., 2010). However, it remains to be determined just how significant these interactions are in determining the relative positioning of loci and genome organization. This is highly pertinent since the correlation between physical positions and distances from the prokaryotic origin (Viollier et al., 2004) or eukaryotic centromere (Therizols et al., 2010) has been observed in systems composed of one type (e.g. linear or circular) of genome and not the multi-chromosome, complex genomes that are also found in prokaryotes.
Given the propensity for prokaryotic genetic material to undergo lateral transfer by transduction, conjugation or transformation (Bushman, 2002), it is reasonable to question whether foreign or mobile sequences become fully integrated into or remain extraneous to the core genome organization. There is also currently little information on how episomes and organelle genomes integrate into the spatial organization of eukaryotic genomes (Binnie et al., 2006; Rodley et al., 2009; Xu and Cook, 2008). The yeast 2-micron plasmid (Rodley et al., 2009; Scott-Drew et al., 2002) and human Epstein-Barr virus (Kapoor and Frappier, 2003; Kapoor et al., 2005) have been shown to interact with chromosomes in a process that is hypothesized to ensure their segregation (Kapoor et al., 2005; Mehta et al., 2002). In these instances, global genome organization is altered as part of a mechanism that is of direct benefit to the parasitic system. Of course, it is also possible that foreign sequences remain as isolated islands within an otherwise unperturbed genomic structure.

\section{Territorial organizations form fragmented genomes} Chromosomes in higher eukaryotes are organized into 'territories' that, while not exclusive for any one chromosome, are enriched for particular chromosomes (Bolzer et al., 2005; Branco and Pombo, 2006; Cremer and Cremer, 2001). Domain or territorial organizations limit the random 


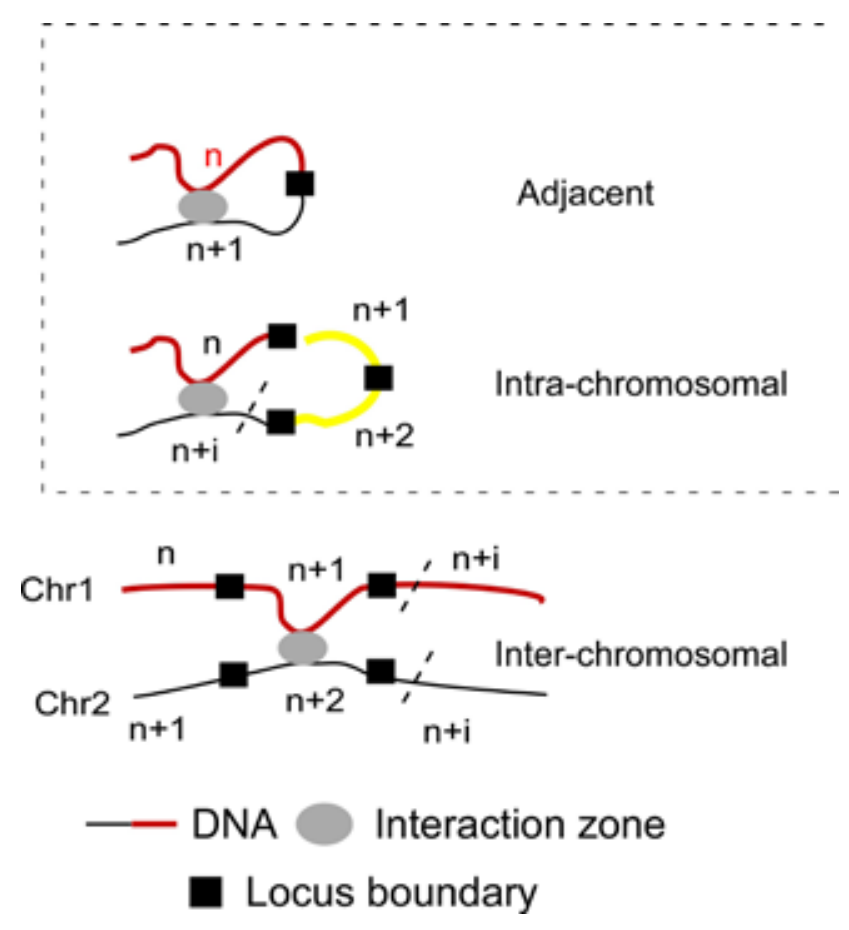

Figure 2. Cartoon illustrating the basic types of chromosomal interactions that occur within a genome. Adjacent interactions are a form of intra-chromosomal interaction, as illustrated by the hatched box. $n$ and $n+i$ denote numbering of loci that, for illustrative purposes only, are separated by boundaries.

association of genomic loci because sequences are only free to move within restricted regions, which are defined by their immediate boundaries (Figure 1A). Chromosomal territories have not been directly observed in $S$. cerevisiae (Meaburn and Misteli, 2007; Saez-Vasquez and Gadal, 2010). However, studies have identified high levels of intrachromosomal connections (Duan et al., 2010; Rodley et al., 2009) and sub-compartmentalization (e.g. Gotta et al., 1996) which are consistent with a territorial organization of the yeast nucleus.

The formation of chromosome territories is a concept that can be easily invoked for prokaryotic species containing complex genomes i.e. multiple chromosomes (Egan et al., 2005), mega-plasmids, and linear chromosomes e.g. Streptomycetes, and pathogenic Spirochaetes (Chen, 1996). This does not mean that the territorial concept does not apply in non-complex prokaryotic genomes, in fact macrodomains (i.e. intra-chromosomal territories) have been identified in prokaryotic genomes (Boccard et al., 2005; Espeli et al., 2008; Maurer et al., 2009; Mercier et al., 2008; Nguyen et al., 2009; Postow et al., 2004; Skoko et al., 2006; Valens et al., 2004). The formation of macrodomains within the non-complex $E$. coli genome results in the separation of the chromosome into six topologically isolated regions (Mercier et al., 2008; Niki et al., 2000; Valens et al., 2004). Although the formation of these macrodomains does not require genome fragmentation into separate chromosomes, the $E$. coli ter domain is maintained by mats and MatP (Mercier et al., 2008) while pars, Spo0J (Lin and Grossman, 1998), ram and RacA (Ben-Yehuda et al., 2005) help define the $B$. subtilis ori domain at different stages during the cell cycle; the intra-domain isolation that results is remarkably similar to that achieved by eukaryotic chromosome territories. Critically, there is little interaction between $E$. coli chromosome macrodomains while intradomain interactions are much more frequent (Valens et al., 2004). Thus, chromosomal macrodomains in non-complex prokaryotic genomes represent an alternative solution to the genome fragmentation that, while maintaining direct physical linkages, reduces the requirement for multiple centromeres and telomeres. Moreover, macrodomain formation also appears to assist in overcoming problems associated with the resolution of chromosome dimers (Galperin, 2007; Postow et al., 2004).

The fact that the frequency of bacterial cell division means that many prokaryotes contain more than one copy of their genome, when growing at or near to maximal growth rates, is of particular relevance to this discussion. The presence of more than one, complete or incomplete, copy of the genome raises the possibility that fully or incompletely replicated chromosomes can interact at the origins of replication or loci that are distinct from the replication fork(s) throughout the entire cell cycle. This is supported by observations of origin of replication clusters for approximately $25 \%$ of the cell cycle in Escherichia coli (Niki and Hiraga, 1998) and Vibrio cholera (Fogel and Waldor, 2005). Therefore, hypothetically it is possible that inter-molecule pairing between identical loci functions as part of a mechanism to regulate (e.g. Spilianakis et al., 2005) expression between identical prokaryotic genes. Such interactions could be regulated by the controlled segregation of loci into chromosomal territories.

\section{The nucleolus: a centre for genome organization}

The nucleolus is the most obvious eukaryotic nuclear subcompartment and epitomizes physical positioning within eukaryotic nuclei. Direct or protein mediated contacts (i.e. interactions) between loci within ribosomal DNA (rDNA) repeats are proposed to make a major contribution to the formation of nucleolar structure (Johnson and Warner, 1989; Kempers-Veenstra et al., 1986). Yet despite intensive investigations into the structure of the nucleolus, there is no widely accepted explanation for its formation or structure. In large part this is due to the repetitive nature of the rDNA limiting our ability to interrogate the structure. Nevertheless, interactions have been observed between the rDNA promoter and terminator regions and these have been proposed to be part of a mechanism that promotes transcription and segregation of the different eukaryotic polymerase systems (Johnson and Warner, 1989; KempersVeenstra et al., 1986). But what relevance does a nucleolus have in complex and non-complex prokaryotic genomes? Simply, E. coli rDNA repeats cluster (Figure 1B) and form a transcription dependent 'nucleolus like structure' (Cabrera and Jin, 2006) that is hypothesized to ensure efficient rRNA synthesis (Cabrera et al., 2009; Cabrera and Jin, 2003). Moreover, alterations to $E$. coli rDNA transcription levels have a significant effect on nucleoid compaction (Cabrera et al., 2009), reinforcing the hypothesis that nucleolar structures are of critical importance in genome organization (Chubb et al., 2002; Leger et al., 1994; O'Sullivan et al., 2009; Stahl et al., 1976; Vogel and Schroeder, 1974). 
A role for prokaryotic rDNA interactions in the compartmentalization of different transcriptional systems is unlikely given that prokaryotes only have one RNA polymerase. Therefore, compartmentalizing the rDNA into a nucleolus-like sub-compartment may serve a different function, namely the separation of loci that are only transcribed from those that are also co-transcriptionally translated. Hence clustering of prokaryotic rDNAs forms a repressive environment for gene or operon expression but not the rDNA, as it is not translated. This would fit with the idea that co-transcriptional coupling of translation in prokaryotes is a factor in shaping these genomes (reviewed in Thanbichler et al., 2005; Zimmerman, 2006). By contrast, the significance of eukaryotic nuclear translation (Hentze, 2001; Iborra et al., 2001), which is involved in mRNA quality control (Fasken and Corbett, 2009), for the shaping of eukaryotic genomes is debatable despite results that implicate the yeast polyA polymerase (Trf4p) in yeast genome organization (O'Sullivan et al., 2009).

\section{Conclusion}

The impression that there is a single chromosome organization within a population of cells grown, at one moment in time, is implicit in many discussions pertaining to spatial organization. This misconception is maintained, unintentionally, by our reliance upon simple images (e.g. Dekker et al., 2002; Rodley et al., 2009) and methodologies that model and portray one solution to complex datasets (e.g. Duan et al., 2010) that describe the probabilities of inter-loci contact. Rather, chromosome organization is likely to be stochastic with many different meta-stable states contributing to an indistinct, 'fuzzy', over-arching population average. Similar issues have previously arisen with respect to stochastic variation about the average mRNA levels within a population of cells (Raj et al., 2006). Despite the predicted stochastic nature of the system, it is unlikely that simply modelling the system as a polymer that has undergone a random or self-avoiding walk and is in thermodynamic equilibrium is sufficient (Tark-Dame et al., In Press). Rather, while it is clear that polymer modelling can provide insights (Marenduzzo et al., 2006; Tark-Dame et al., In Press), deterministic structural elements (e.g. centromere/origin localisation and nucleolus/nucleolus like formation) play a role. However, the contribution that deterministic elements make to the over-arching structure in comparison to the physical properties of the DNA polymer itself remains to be conclusively determined. Finally, while modelling can provide insights, it cannot replace empirical evidence that links structural features to biologically relevant functional outcomes.

The formation of domains or territories within genomes alleviates molecular crowding effects by compartmentalizing transcriptional, translational, replication or repair factors in non-membrane bound sub-domains. Moreover, domain formation controls interactions between loci that are coexpressed or co-replicated. Yet, numerous questions that relate to the universality of the systems that organize genome structure remain to be answered. In particular, is genome organization actively or passively derived from the preceding cellular division? If the initial organization is actively arrived at, is it only the centromeric/origin associated sequences that are required? Moreover, how are the mechanisms that act to coordinate this inter- and intra-chromosomal organization relate to the cell cycle and differ in systems that have linear, circular or mixed genomes? Do these differences predominantly arise due to the presence of a single or multiple replication origins? In complex unicellular genomes, do inter-domain and interepisome interactions occur between operons as part of a mechanism that increases the sensitivity and fine tuning of promoters? If not, do these complex unicellular systems coordinate inter-domain organization and communication, or is such communication unnecessary in the absence of physical compartmentalization of the transcription and translational machinery? Finally, it is interesting to speculate that one of the most ancient enzymes (i.e. the ribosome) is the keystone in the organization of metabolic pathways not only through its enzymatic role in making proteins, but also as a result of a critical role the rDNA plays in organizing the three-dimensional spatial arrangement of genomes.

\section{Acknowledgements}

Thanks to R. McNab and A. Ganley for comments on the manuscript. Work in the author's laboratory is sponsored by the Auckland Medical Research Foundation, the Maurice and Phyllis Paykel Trust, and the Marsden fund. Thanks also to the anonymous referees for their insightful comments and guidance.

\section{References}

Balaeff, A., Mahadevan, L., and Schulten, K. (2004). Structural basis for cooperative DNA binding by CAP and lac repressor. Structure 12, 123-132.

Ben-Yehuda, S., Fujita, M., Liu, X.S., Gorbatyuk, B., Skoko, D., Yan, J., Marko, J.F., Liu, J.S., Eichenberger, P., Rudner, D.Z., et al. (2005). Defining a centromere-like element in Bacillus subtilis by Identifying the binding sites for the chromosome-anchoring protein RacA. Mol Cell 17, 773-782.

Ben-Yehuda, S., Rudner, D.Z., and Losick, R. (2003). RacA, a bacterial protein that anchors chromosomes to the cell poles. Science $299,532-536$.

Berger, A.B., Cabal, G.G., Fabre, E., Duong, T., Buc, H., Nehrbass, U., Olivo-Marin, J.C., Gadal, O., and Zimmer, C. (2008). High-resolution statistical mapping reveals gene territories in live yeast. Nat Methods 5, 1031-1037.

Binnie, A., Castelo-Branco, P., Monks, J., and Proudfoot, N.J. (2006). Homologous gene sequences mediate transcription-domain formation. J Cell Sci 119, 38763887.

Bischof, M. (2003). Introduction to integrative biophysics. In Integrative Biophysics, F.A. Popp, and L. Beloussov, eds. (Dordrecht, Kluwer Academic Publishersq), p. 503.

Boccard, F., Esnault, E., and Valens, M. (2005). Spatial arrangement and macrodomain organization of bacterial chromosomes. Molecular Microbiology 57, 9-16.

Bolzer, A., Kreth, G., Solovei, I., Koehler, D., Saracoglu, K., Fauth, C., Muller, S., Eils, R., Cremer, C., Speicher, M.R., et al. (2005). Three-Dimensional Maps of All Chromosomes in Human Male Fibroblast Nuclei and Prometaphase Rosettes. PLoS Biology 3, e157.

Branco, M.R., and Pombo, A. (2006). Intermingling of chromosome territories in interphase suggests role in translocations and transcription-dependent associations. PLoS Biology 4, 780-788. 
Breier, A.M., and Cozzarelli, N.R. (2004). Linear ordering and dynamic segregation of the bacterial chromosome. Proc Natl Acad Sci U S A 101, 9175-9176.

Bushman, F. (2002). Lateral DNA transfer (New York Cold Spring Harbor Laboratory Press).

Bystricky, K., Heun, P., Gehlen, L., Langowski, J., and Gasser, S.M. (2004). Long-range compaction and flexibility of interphase chromatin in budding yeast analyzed by high-resolution imaging techniques. Proc Natl Acad Sci USA 101, 16495-16500.

Bystricky, K., Laroche, T., van Houwe, G., Blaszczyk, M., and Gasser, S.M. (2005). Chromosome looping in yeast: telomere pairing and coordinated movement reflect anchoring efficiency and territorial organization. J Cell Biol 168, 375-387.

Cabrera, J.E., Cagliero, C., Quan, S., Squires, C.L., and Jin, D.J. (2009). Active transcription of rRNA operons condenses the nucleoid in Escherichia coli: examining the effect of transcription on nucleoid structure in the absence of transertion. J Bacteriol 191, 4180-4185.

Cabrera, J.E., and Jin, D.J. (2003). The distribution of RNA polymerase in Escherichia coli is dynamic and sensitive to environmental cues. Mol Microbiol 50, 1493-1505.

Cabrera, J.E., and Jin, D.J. (2006). Active transcription of rRNA operons is a driving force for the distribution of RNA polymerase in bacteria: effect of extrachromosomal copies of $r r n B$ on the in vivo localization of RNA polymerase. J Bacteriol 188, 4007-4014.

Chen, C.W. (1996). Complications and implications of linear bacterial chromosomes. Trends Genet 12, 192-196.

Chubb, J.R., Boyle, S., Perry, P., and Bickmore, W.A. (2002). Chromatin motion is constrained by association with nuclear compartments in human cells. Curr Biol 12, 439-445.

Comings, D.E. (1968). The rationale for an ordered arrangement of chromatin in the interphase nucleus. Am J Hum Genet 20, 440-460.

Cremer, T., and Cremer, C. (2001). Chromosome territories, nuclear architecture and gene regulation in mammalian cells. Nat Rev Genet 2, 292-301.

Dandanell, G., Valentin-Hansen, P., Larsen, J.E., and Hammer, K. (1987). Long-range cooperativity between gene regulatory sequences in a prokaryote. Nature 325 , 823-826.

Dekker, J., Rippe, K., Dekker, M., and Kleckner, N. (2002). Capturing chromosome conformation. Science 295, 1306-1311.

Duan, Z., Andronescu, M., Schutz, K., Mcllwain, S., Kim, Y.J., Lee, C., Shendure, J., Fields, S., Blau, C.A., and Noble, W.S. (2010). A three-dimensional model of the yeast genome. Nature 465, 363-367.

Egan, E.S., Fogel, M.A., and Waldor, M.K. (2005). Divided genomes: negotiating the cell cycle in prokaryotes with multiple chromosomes. Mol Microbiol 56, 1129-1138.

Espeli, O., Mercier, R., and Boccard, F. (2008). DNA dynamics vary according to macrodomain topography in the E. coli chromosome. Mol Microbiol 68, 1418-1427.

Fasken, M.B., and Corbett, A.H. (2009). Mechanisms of nuclear mRNA quality control. RNA Biol 6, 237-241.

Fiebig, A., Keren, K., and Theriot, J.A. (2006). Fine-scale time-lapse analysis of the biphasic, dynamic behaviour of the two Vibrio cholerae chromosomes. Mol Microbiol 60, 1164-1178.
Fogel, M.A., and Waldor, M.K. (2005). Distinct segregation dynamics of the two Vibrio cholerae chromosomes. Molecular Microbiology 55, 125-136.

Galperin, M.Y. (2007). Linear chromosomes in bacteria: no straight edge advantage? Environ Microbiol 9, 13571362.

Gotta, M., Laroche, T., Formenton, A., Maillet, L., Scherthan, H., and Gasser, S.M. (1996). The clustering of telomeres and colocalization with Rap1, Sir3, and Sir4 proteins in wild-type Saccharomyces cerevisiae. J Cell Biol 134, 1349-1363.

Hentze, M.W. (2001). Protein Synthesis: Believe it or not: Translation in the nucleus. Science 293, 1058-1059.

Iborra, F.J., Jackson, D.A., and Cook, P.R. (2001). Coupled transcription and translation within nuclei of mammalian cells. Science 293, 1139-1142.

Johnson, S.P., and Warner, J.R. (1989). Unusual enhancer function in yeast rRNA transcription. Mol Cell Biol 9, 49864993.

Kapoor, P., and Frappier, L. (2003). EBNA1 partitions Epstein-Barr virus plasmids in yeast cells by attaching to human EBNA1-binding protein 2 on mitotic chromosomes. J Virol 77, 6946-6956.

Kapoor, P., Lavoie, B.D., and Frappier, L. (2005). EBP2 plays a key role in Epstein-Barr virus mitotic segregation and is regulated by aurora family kinases. Mol Cell Biol 25, 4934-4945.

Kauffman, S.A. (1993). The origins of order: self organization and selection in evolution. . 709 .

Kempers-Veenstra, A.E., Oliemans, J., Offenberg, H., Dekker, A.F., Piper, P.W., Planta, R.J., and Klootwijk, J. (1986). 3'-End formation of transcripts from the yeast rRNA operon. EMBO J 5, 2703-2710.

Leger, I., Guillaud, M., Krief, B., and Brugal, G. (1994). Interactive computer-assisted analysis of chromosome 1 colocalization with nucleoli. Cytometry 16, 313-323.

Lin, D.C., and Grossman, A.D. (1998). Identification and characterization of a bacterial chromosome partitioning site. Cell 92, 675-685.

Liu, X., Wang, X., Reyes-Lamothe, R., and Sherratt, D. (2010). Replication-directed sister chromosome alignment in Escherichia coli. Molecular Microbiology 75, 10901097.

Livny, J., Yamaichi, Y., and Waldor, M.K. (2007). Distribution of centromere-like parS sites in bacteria: insights from comparative genomics. J Bacteriol 189, 8693-8703.

Marenduzzo, D., Finan, K., and Cook, P.R. (2006). The depletion attraction: an underappreciated force driving cellular organization

10.1083/jcb.200609066. J Cell Biol 175, 681-686.

Martin, M., Cho, J., Cesare, A.J., Griffith, J.D., and Attardi, G. (2005). Termination Factor-Mediated DNA Loop between Termination and Initiation Sites Drives Mitochondrial rRNA Synthesis. Cell 123, 1227-1240.

Maurer, S., Fritz, J., and Muskhelishvili, G. (2009). A systematic in vitro study of nucleoprotein complexes formed by bacterial nucleoid-associated proteins revealing novel types of DNA organization. J Mol Biol 387, 12611276.

Meaburn, K.J., and Misteli, T. (2007). Cell biology: chromosome territories. Nature 445, 379-781.

Mehta, S., Yang, X.M., Chan, C.S., Dobson, M.J., Jayaram, M., and Velmurugan, S. (2002). The 2 micron plasmid 
purloins the yeast cohesin complex: a mechanism for coupling plasmid partitioning and chromosome segregation? J Cell Biol 158, 625-637.

Mercier, R., Petit, M.A., Schbath, S., Robin, S., El Karoui, M., Boccard, F., and Espéli, O. (2008). The MatP/matS Site-Specific System Organizes the Terminus Region of the E. coli Chromosome into a Macrodomain. Cell 135, 475-485.

Miele, A., Bystricky, K., and Dekker, J. (2009). Yeast silent mating type loci form heterochromatic clusters through silencer protein-dependent long-range interactions. PLoS Genet 5, e1000478.

Nguyen, H.H., de la Tour, C.B., Toueille, M., Vannier, F., Sommer, S., and Servant, P. (2009). The essential histone-like protein HU plays a major role in Deinococcus radiodurans nucleoid compaction. Mol Microbiol 73, 240252.

Nicolis, G., and Prigogine, I. (1977). Self-Organization in Nonequilibrium Systems (New York, Wiley-Interscience).

Niki, H., and Hiraga, S. (1998). Polar localization of the replication origin and terminus in Escherichia coli nucleoids during chromosome partitioning. Genes Dev 12, 1036-1045.

Niki, H., Yamaichi, Y., and Hiraga, S. (2000). Dynamic organization of chromosomal DNA in Escherichia coli. Genes Dev 14, 212-223.

O'Sullivan, J., Sontam, D.M., Grierson, R., and Jones, B. (2009). Repeated elements coordinate the spatial organization of the yeast genome. Yeast 26, 125-138.

O'Sullivan, J.M. Yeast chromosomal interactions and nuclear architecture. Current Opinion in Cell Biology 22, 298-304.

Postow, L., Hardy, C.D., Arsuaga, J., and Cozzarelli, N.R. (2004). Topological domain structure of the Escherichia coli chromosome. Genes Dev 18, 1766-1779.

Prigogine, I. (1980). From being to becoming: time and complexity in the physical sciences (San Francisco, W.H. Freeman and Company).

Raj, A., Peskin, C.S., Tranchina, D., Vargas, D.Y., and Tyagi, S. (2006). Stochastic mRNA synthesis in mammalian cells. PLoS Biol 4, e309.

Rocha, E.P. (2008). The organization of the bacterial genome. Annu Rev Genet 42, 211-233.

Rodley, C.D., Bertels, F., Jones, B., and O'Sullivan, J.M. (2009). Global identification of yeast chromosome interactions using Genome conformation capture. Fungal Genet Biol 46, 879-886.

Saez-Vasquez, J., and Gadal, O. (2010). Genome organization and function: a view from yeast and Arabidopsis. Mol Plant 3, 678-690.

Schleif, R. (1992). DNA looping. Annu Rev Biochem 61, 199-223.

Scott-Drew, S., Wong, C.M., and Murray, J.A. (2002). DNA plasmid transmission in yeast is associated with specific sub-nuclear localisation during cell division. Cell Biol Int 26, 393-405.
Skoko, D., Yoo, D., Bai, H., Schnurr, B., Yan, J., McLeod, S.M., Marko, J.F., and Johnson, R.C. (2006). Mechanism of chromosome compaction and looping by the Escherichia coli nucleoid protein Fis. J Mol Biol 364, 777-798.

Spilianakis, C.G., Lalioti, M.D., Town, T., Lee, G.R., and Flavell, R.A. (2005). Interchromosomal associations between alternatively expressed loci. Nature 435, 637-645.

Stahl, A., Hartung, M., Vagner-Capodano, A.M., and Fouet, C. (1976). Chromosomal constitution of nucleolusassociated chromatin in man. Hum Genet 35, 27-34.

Swigon, D., Coleman, B.D., and Olson, W.K. (2006). Modeling the Lac repressor-operator assembly: The influence of DNA looping on Lac repressor conformation. Proc. Natl. Acad. Sci. USA 103, 9879-9884.

Tark-Dame, M., van Driel, R., and Heermann, D.W. (In Press). Chromatin folding: from biology to polymer models and back. J. Cell Sci.

Thanbichler, M., Wang, S.C., and Shapiro, L. (2005). The bacterial nucleoid: a highly organized and dynamic structure. J Cell Biochem 96, 506-521.

Therizols, P., Duong, T., Dujon, B., Zimmer, C., and Fabre, E. (2010). Chromosome arm length and nuclear constraints determine the dynamic relationship of yeast subtelomeres. Proc Natl Acad Sci USA 107, 2025-2030.

Toro, E., and Shapiro, L. (2010). Bacterial chromosome organization and segregation. Cold Spring Harb Perspect Biol 2, a000349.

Valens, M., Penaud, S., Rossignol, M., Cornet, F., and Boccard, F. (2004). Macrodomain organization of the Escherichia coli chromosome. EMBO J 23, 4330-4341.

Viollier, P.H., Thanbichler, M., McGrath, P.T., West, L., Meewan, M., McAdams, H.H., and Shapiro, L. (2004). Rapid and sequential movement of individual chromosomal loci to specific subcellular locations during bacterial DNA replication. Proc Natl Acad Sci USA 101, 9257-9262.

Vogel, F., and Schroeder, T.M. (1974). The internal order of the interphase nucleus. Humangenetik 25, 265-297.

Von Bertalanffy, L. (1950). The theory of open systems in physics and biology. Science 111, 23-29.

White, M.A., Eykelenboom, J.K., Lopez-Vernaza, M.A., Wilson, E., and Leach, D.R. (2008). Non-random segregation of sister chromosomes in Escherichia coli. Nature 455, 1248-1250.

Wiggins, P.A., Cheveralls, K.C., Martin, J.S., Lintner, R., and Kondev, J. (2010). Strong intranucleoid interactions organize the Escherichia coli chromosome into a nucleoid filament. Proc Natl Acad Sci U S A 107, 4991-4995.

Xu, M., and Cook, P.R. (2008). Similar active genes cluster in specialized transcription factories. J Cell Biol 181, 615623.

Zimmerman, S.B. (2006). Shape and compaction of Escherichia coli nucleoids. J Struct Biol 156, 255-261. 


\section{Further Reading}

Caister Academic Press is a leading academic publisher of advanced texts in microbiology, molecular biology and medical research. Full details of all our publications at caister.com

- MALDI-TOF Mass Spectrometry in Microbiology Edited by: M Kostrzewa, S Schubert (2016) www.caister.com/malditof

- Aspergillus and Penicillium in the Post-genomic Era Edited by: RP Vries, IB Gelber, MR Andersen (2016) www.caister.com/aspergillus2

- The Bacteriocins: Current Knowledge and Future Prospects Edited by: RL Dorit, SM Roy, MA Riley (2016)

www.caister.com/bacteriocins

- Omics in Plant Disease Resistance Edited by: V Bhadauria (2016) www.caister.com/opd

- Acidophiles: Life in Extremely Acidic Environments Edited by: R Quatrini, DB Johnson (2016) www.caister.com/acidophiles

- Climate Change and Microbial Ecology: Current Research and Future Trend

Edited by: J Marxsen (2016)

www.caister.com/climate

- Biofilms in Bioremediation: Current Research and Emerging Technologies

Edited by: G Lear (2016)

www.caister.com/biorem

- Microalgae: Current Research and Applications Edited by: MN Tsaloglou (2016) www.caister.com/microalgae

- Gas Plasma Sterilization in Microbiology: Theory, Applications, Pitfalls and New Perspectives Edited by: H Shintani, A Sakudo (2016) www.caister.com/gasplasma

- Virus Evolution: Current Research and Future Directions Edited by: SC Weaver, M Denison, M Roossinck, et al. (2016) www.caister.com/virusevol

- Arboviruses: Molecular Biology, Evolution and Control Edited by: N Vasilakis, DJ Gubler (2016) www.caister.com/arbo

- Shigella: Molecular and Cellular Biology Edited by: WD Picking, WL Picking (2016) www.caister.com/shigella

-Aquatic Biofilms: Ecology, Water Quality and Wastewater Treatment

Edited by: AM Romaní, H Guasch, MD Balaguer (2016)

www.caister.com/aquaticbiofilms

- Alphaviruses: Current Biology

Edited by: S Mahalingam, L Herrero, B Herring (2016)

www.caister.com/alpha

- Thermophilic Microorganisms

Edited by: F Li (2015)

www.caister.com/thermophile
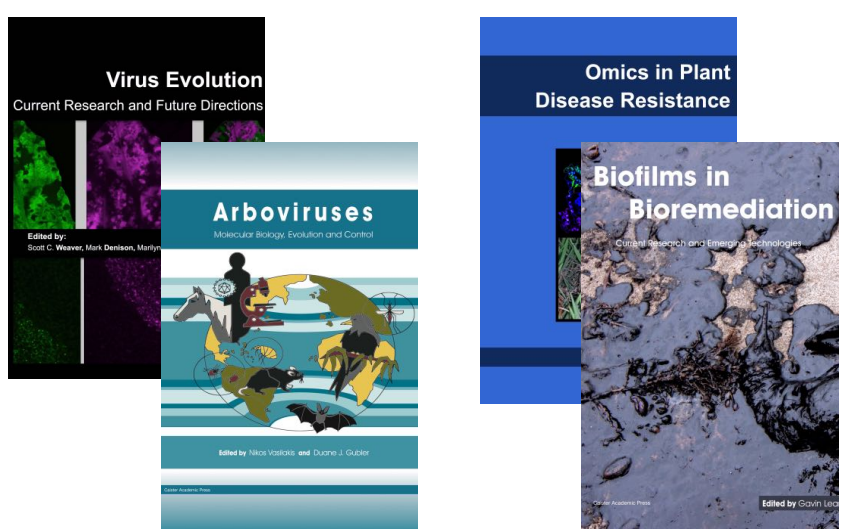
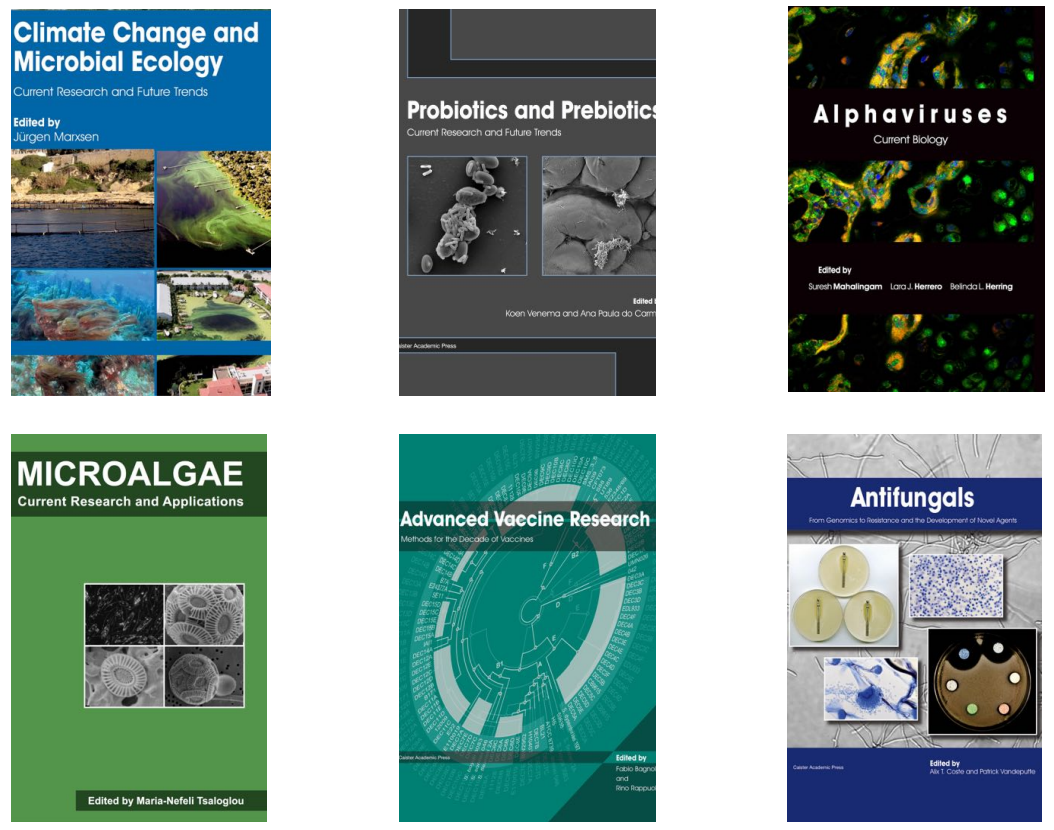

- Flow Cytometry in Microbiology: Technology and Applications Edited by: MG Wilkinson (2015) www.caister.com/flow

- Probiotics and Prebiotics: Current Research and Future Trends Edited by: K Venema, AP Carmo (2015) www.caister.com/probiotics

- Epigenetics: Current Research and Emerging Trends Edited by: BP Chadwick (2015) www.caister.com/epigenetics2015

- Corynebacterium glutamicum: From Systems Biology to Biotechnological Applications

Edited by: A Burkovski (2015)

www.caister.com/cory2

- Advanced Vaccine Research Methods for the Decade of Vaccines

Edited by: F Bagnoli, R Rappuoli (2015)

www.caister.com/vaccines

- Antifungals: From Genomics to Resistance and the Development of Novel Agents

Edited by: AT Coste, P Vandeputte (2015)

www.caister.com/antifungals

- Bacteria-Plant Interactions: Advanced Research and Future Trends Edited by: J Murillo, BA Vinatzer, RW Jackson, et al. (2015) www.caister.com/bacteria-plant

\section{- Aeromonas}

Edited by: J Graf (2015)

www.caister.com/aeromonas

- Antibiotics: Current Innovations and Future Trends

Edited by: S Sánchez, AL Demain (2015)

www.caister.com/antibiotics

- Leishmania: Current Biology and Contro Edited by: S Adak, R Datta (2015) www.caister.com/leish2

- Acanthamoeba: Biology and Pathogenesis (2nd edition) Author: NA Khan (2015)

www.caister.com/acanthamoeba2

- Microarrays: Current Technology, Innovations and Applications Edited by: Z He (2014)

www.caister.com/microarrays2

- Metagenomics of the Microbial Nitrogen Cycle: Theory, Methods and Applications

Edited by: D Marco (2014)

www.caister.com/n2 